\title{
Outcomes of Treatment for Glioblastoma Multiforme in Adult Patients: A Single Institution Experience from the Eastern Black Sea Region of Turkey
}

\author{
Mustafa KANDAZ ${ }^{1}$, Zumrut BAHAT ${ }^{1}$, Ozan C. GULER ${ }^{1}$, Emine CANYILMAZ ${ }^{1}$, \\ Ugur YAZAR ${ }^{2}$, Adnan YONEY ${ }^{1}$ \\ ${ }^{1}$ Karadeniz Technical University Faculty of Medicine, Department of Radiation Oncology \\ ${ }^{2}$ Karadeniz Technical University Faculty of Medicine, Department of Brain Surgery, Trabzon, TURKEY
}

\begin{abstract}
The aim of the present study was to observe the relationship between age distribution and overall survival in glioblastoma multiforme. A series of 274 glioblastoma patients were analyzed retrospectively. Patients received chemoradiation with temozolomide. For the whole population, median overall survival time was $9.80 \pm 1.78(95 \% \mathrm{Cl}, 6.31-13.28)$ months and 1-, 2- and 3- years survival rates were $38.3 \%, 16.1 \%$ and $8.4 \%$ respectively. Median survival time of the patients $\leq 5$ th, 6 th, 7 th and $\geq 8$ th decade $26.00 \pm 7.12$, $14.42 \pm 3.07,13.65 \pm 2.14$ and $5.25 \pm 0.73$ respectively. There were a statistically significant difference in median survival rates among the four groups $(p<0.001)$. GBM remains a poor prognosis and fatal brain tumor despite the availability of multimodal treatment options. Age can be considered as the most important prognostic factor in patients with GBM as elderly patients have an extremely poor prognosis. Further research is thus warranted for the selection of treatment options that can improve the OS as well as ensure quality of life in the adult patients.
\end{abstract}

Keywords: Glioblastoma Multiforme, Age, Overall survival

\section{ÖZET}

\section{Erişkin Hastalarda GBM Tedavisinin Sonuçları: Doğu Karadeniz Bölgesi’ndeki Tek Bir Kurum Tecrübesi}

Bu çalışmanın amacı, glioblastoma multiformede yaş dağılımı ve genel sağkalım arasındaki ilişkiyi incelemektir. 274 Glioblastoma multiformeli hasta retrospektif olarak incelendi. Hastaların hepsi temazolamidli kemoradyoterapi aldı. Tüm hastalar için medyan genel

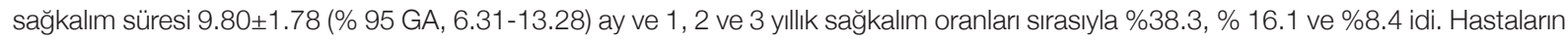
medyan sağkalım süresi $\leq 5,6,7$ ve $\geq 8$ dekatta sırasılla 26.00 $\pm 7.12,14.42 \pm 3.07,13.65 \pm 2.14$ ve $5.25 \pm 0.73$ idi. Dört grup arasında medyan sağkalım oranlarında istatistiksel olarak anlamlı farklılık vardı $(p<0.001)$. GBM, multimodal tedaviye rağmen kötü prognozlu ve ölümcül bir beyin tümörüdür Yaş, GBM’li hastalarda en önemli prognostik faktör olarak düşünülebilir, çünkü yaşılı hastalarda prognoz oldukça kötüdür. Bu nedenle, yetişkin hastalarda yaşam kalitesini arttırmanın yanı sıra ortalama sağkalımı artırabilecek tedavi seçenekleri için daha fazla araştırmaya intiyaç vardır.

Anahtar Kelimeler: Glioblastoma multiforme, Yaş, Genel sağkalım 


\section{INTRODUCTION}

More than half of the brain tumors are malignant glioma (WHO Grade III-IV), and approximately $75 \%$ of them are glioblastoma multiforme (GBM). GBM is the most aggressive primary malignant tumor of the central nervous system. ${ }^{1,2}$ While it can occur at any age, its prevalence peaks between the sixth and seventh decade of life. The median age at diagnosis of GBM is 64 years in the USA, 63 years in France, and 62 years in the eastern Black Sea region of Turkey. More than one-quarter of the GBM cases occur in patients of age $\geq 70$ years. In the recent past, an increase in the brain tumor mortality has been noted with an increase in the occurrence of age-standardized incidences of GBM. ${ }^{3-5}$

The standard treatment of GBM is complete surgical excision of the tumor, based on the trial described by Stupp et al. ${ }^{6}$ However, because of its high local recurrence rate, a need has been recognized for adjuvant therapies after surgical treatment. The combined randomized phase III study conducted by Stupp et al. ${ }^{6}$ with the European Organization for Research and Treatment of Cancer (EORTC)/National Cancer Institute of Canada (NCIC) groups demonstrated that the addition of chemotherapy (CT) with $75 \mathrm{mg} / \mathrm{m}^{2}$ temozolomide (TMZ) - which is an oral alkylating agent-and 5 cycles $\left(200 \mathrm{mg} / \mathrm{m}^{2}\right)$ of adjuvant CT simultaneously with the standard conventional radiotherapy (RT) could significantly extend the overall survival (OS) of the patients in comparison with that by administration of RT alone. As a result, the current literature considers "surgery + simultaneous CT-RT + adjuvant CT" as the standard treatment for GBM. ${ }^{7}$

The median OS for patients diagnosed with glioblastoma is approximately $12-15$ months. ${ }^{6}$ However, retrospective studies have indicated a median OS of approximately 4-8 months for patients with glioblastoma and age $>65$ years, inclusive of all treatment modalities. ${ }^{8-10}$ Through this study, we aimed to investigate the effect of age on the OS in GBM cases.

\section{MATERIALS AND METHODS}

This retrospective clinical study was conducted with due permission from the Ethics Committee at the Karadeniz Technical University Faculty of Medicine (2017-107). Between 2000 and 2016 patients records were evaluated. Patients' information about their age, gender, surgical history, and survival were recorded. The patients were grouped by age. Patients who did not receive TMZ treatment were excluded from the study. A total of 274 patients with the diagnosis of GBM by pathology or radiology were included in this study.

\section{Treatment}

Computerized tomography was performed before RT. The mass or surgical bed was fused with Magnetic Resonance Imaging (MRG) present before the surgical treatment. The optical nerves, lenses, pituitary gland, optical chiasm, and brain stem were contoured as critical organs. The threedimensional conformal RT or intensity modulated RT techniques were used for diagnostic purpose. In RT planning, in the absence of edema, the mass or mass bed was described as gross tumor volume- 2 (GTV2), while, in the presence of edema, it was described as GTV1. The clinical tumor volume (CTV) was forged with 2-cm margins assigned to GTV1 or GTV2. The CTV was excluded from anatomic barriers in the absence of an extension. The planned target volume (PTV) was forged with 0.5$\mathrm{cm}$ margins assigned to the CTV. Two Gy each for 23 fractions (totaling $46 \mathrm{~Gy}$ ) were assigned to the PTV1 and 2Gy/7 fractions (totaling $14 \mathrm{~Gy}$ ) were assigned to the PTV2, resulting in the grand total tumor dose of 60 Gy. For 6 weeks, everyday, an oral administration of $75 \mathrm{mg} / \mathrm{m}^{2} \mathrm{TMZ}$ was applied as simultaneous CT. After RT, at every 28 days, for 5 consecutive days, five cycles of $200 \mathrm{mg} / \mathrm{m}^{2} \mathrm{TMZ}$ was applied.

\section{Follow-up}

After 2 months of RT, the patients' were clinically examined and their complete blood test and MRG controls were performed. The OS was considered as the time between diagnosis and the last control or death date.

\section{Statistical Methods}

The obtained data were subjected to the statistical analysis by using the SPSS (SPSS for Windows, 


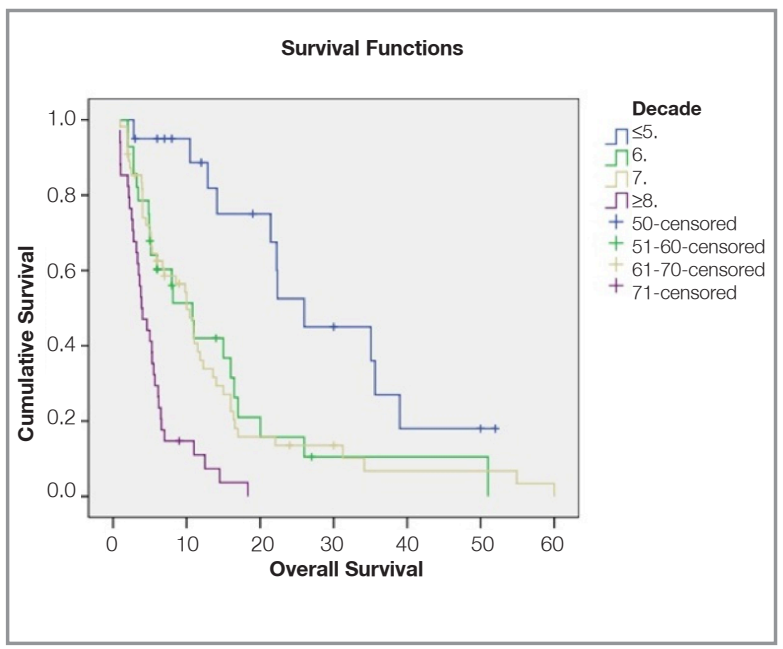

Figure 1: Overall survival of glioblastome multiforme patients according to age $(n=274)$

Version 16.0. Chicago, USA) software. The OS was estimated by using the Kaplan-Meier methods. The survival differences between the groups were examined by using the log-rank test. All tests were considered statistically significant at $\mathrm{p}<0.05$.

\section{RESULTS}

Of the 274 patients included in the study, 170 $(62 \%)$ were men, of which $26(10 \%)$ were in their fifties, $32(11 \%)$ in their sixties, $72(26 \%)$ in seventies, and $40(15 \%)$ were aged $>80$ years. In addition, $104(38 \%)$ of the patients were women, of which $14(5 \%)$ were in their fifties, $24(9 \%)$ in their sixties, $38(14 \%)$ in their seventies, and 28 $(10 \%)$ were of age $>80$ years. The median patient age was 63 years (age range: 7-88 years). Overall, $40(15 \%)$ patients were aged $\leq 50$ years, $56(20 \%)$ fell within the age range of $\geq 51$ to $\leq 60$ years, 110 (40\%) were aged $\geq 61$ to $\leq 70$ years, and $68(25 \%)$ were aged $\geq 71$ years.

Among the 86 (31\% of total) medically inoperable patients diagnosed radiologically, $8(3 \%)$ were in their fifties, $20(7 \%)$ in their sixties, $30(11 \%)$ in their seventies, and $28(10 \%)$ were of age $>80$ years. Moreover, from the 106 (39\%) patients who underwent operation, biopsy, or subtotal excision, $14(5 \%)$ were in their fifties, $22(8 \%)$ in their sixties, $46(17 \%)$ in their seventies, and $24(9 \%)$ were aged $>80$ years. Total excision was made in 82
(30\%) patients, of which 18 (7\%) were in their fifties, $14(5 \%)$ in their sixties, $34(12 \%)$ in their seventies, and $16(6 \%)$ were aged $>80$ years.

\section{Survival}

For the entire cohort, the median OS time was $9.80 \pm 1.78$ (standard deviation) months $(95 \% \mathrm{CI}$, 6.31-13.28) and the 1-, 2-, and 3-year survival rates were $38.3 \%, 16.1 \%$, and $8.4 \%$, respectively. The median OS and the 1-, 2-, and 3-year survival rates of patients in their fifties were $26.00 \pm 7.12$ months (95\% CI: $12.04-39.95)$ and $88.7 \%, 52.5 \%$, and $18 \%$, respectively; for those in their sixties, were $10.80 \pm 2.14$ months (95\% CI: 6.59-15.00) and $42 \%, 10.5 \%$, and $10.5 \%$, respectively; and for those in their seventies, were $10.00 \pm 1.25$ months (95\% CI: $7.54-12.45)$ and $33.9 \%, 13.5 \%$, and $6.8 \%$, respectively. For patients aged $>80$ years, the median OS was $3.86 \pm 0.72$ months $(95 \% \mathrm{CI}$ : 2.43-5.29) and the 1-year survival rate was 7.4\%, with no patient being alive after 2 years. A statistically significant difference was noted in the median survival rates among the four groups $(\mathrm{p}<0.001)$ (Figure 1). On comparing the data from different age groups, a statistically significant difference was noted in the fifth decade of life as compared with that in the sixth $(\mathrm{p}=0003)$, seventh $(\mathrm{p}<0.001)$, and eighth $(p<0.001)$ decades. No statistically significant difference $(\mathrm{p}=0.896)$ was noted between the patients in their sixth and seventh decades of life, albeit a statistically significant difference $(\mathrm{p}<$ 0.001 ) was identified between those in their sixth and eight decades and between those in their seventh and eighth decades of life $(\mathrm{p}<0.001)$.

With reference to the gender, the median OS and the 1-, 2-, and 3-year survival rates for men and women were $10.00 \pm 2.07$ months (95\% CI: 5.93 14.06 ) and $37.4 \%, 14 \%$, and $11.2 \%$ and $8.00 \pm 3.03$ months (95\% CI: 2.04-13.95) and 37.2\%, 19.6\%, and $5.6 \%$, respectively, with a statistically significant difference of $\mathrm{p}<0.001$.

With reference to the surgery types, the patients diagnosed radiologically showed a median OS of $5.53 \pm 0.77$ months (95\% CI: 4.00-7.05) and their $1-, 2-$, and 3-year survival rates were $24.3 \%, 8.1 \%$, and $6.8 \%$, respectively, with no patient being alive 
International Journal of Hematology and Oncology

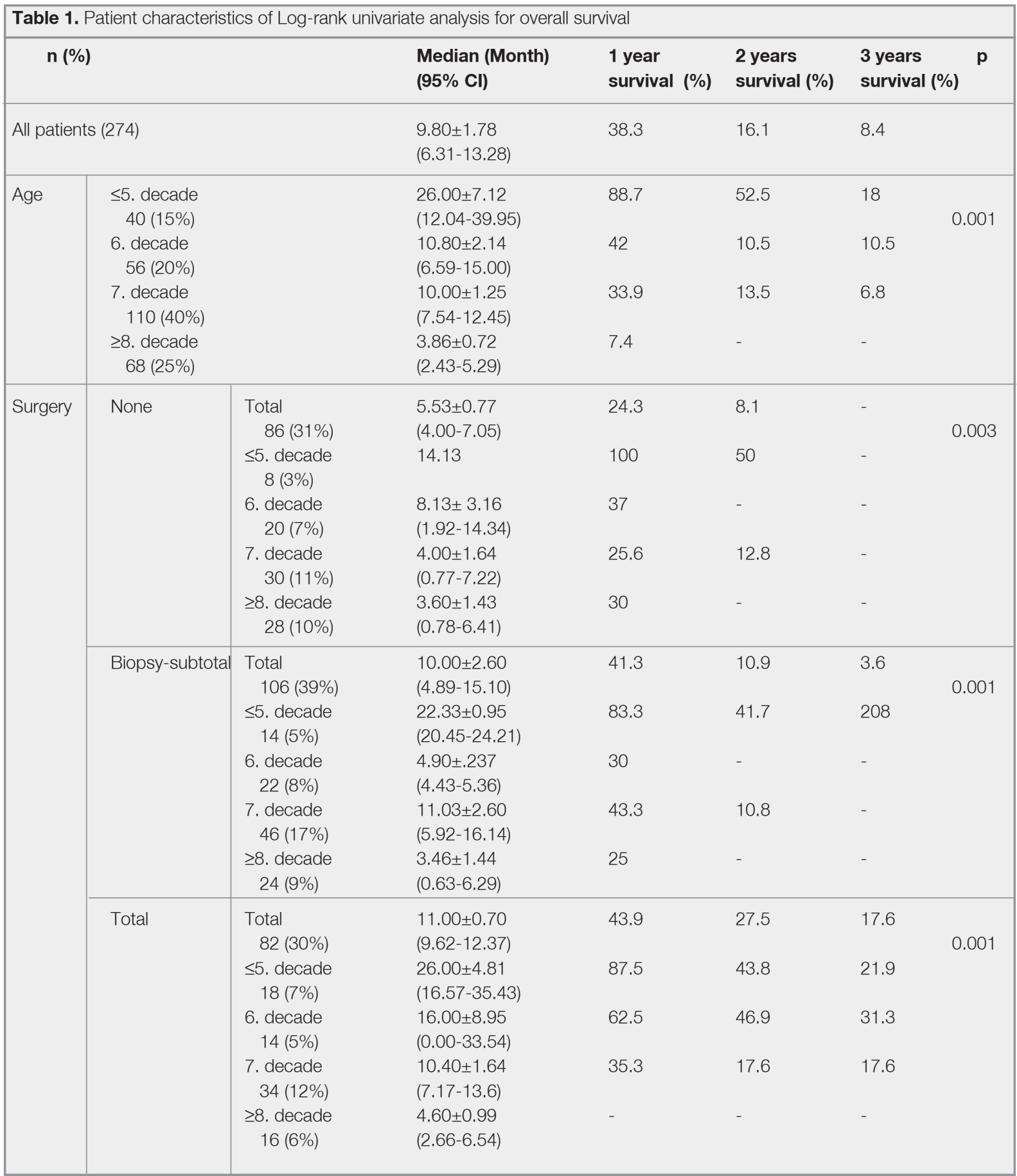

after 3 years. In patients who had undergone applied biopsy or subtotal excision, the median OS was $10.00 \pm 2.60$ months (95\% CI: 4.89-15.10) and their 1-, 2-, and 3-year survival rates were $41.3 \%, 10.9 \%$, and $3.6 \%$, respectively. In patients who underwent total excision, the median survival time was $11.00 \pm 0.70$ months $(95 \% \mathrm{CI}$ :
9.62-12.37) and their 1-, 2-, and 3-year survival rates were $43.9 \%, 27.5 \%$, and $17.6 \%$, respectively. A statistically significant difference was noted in the median survival rates among the three groups $(\mathrm{p}<0.001)$ (Table 1). 


\section{DISCUSSION}

Brain tumors are rarer than other malignancies; however, they are associated with high mortality rate. GBM is an incurable and a very common primary malign brain tumor. The first priority treatment for this disease is the total excision of the tumor. Because local recurrences are inevitable in these cases, there is an urgent need for an adjuvant treatment option.

Although GBM can occur at any age, its median age of occurrence is 64 years. Over the last 50 years, an increase in the age-standardized incidences of GBM has been noted to be related to an increase in the brain tumor mortality. The mortality rate peaks between the sixth and seventh decades of life. ${ }^{3-5}$ In the present study, the median age of the patients was 63 months, which concurs with previously reported data. ${ }^{3-5}$ These observations explain why patients in their sixth and seventh decades of life had similar outcomes in our study.

Based on the landmark EORTC/NCIC randomized trial by Stupp et al. in 2005, which demonstrated improved survival with the addition of TMZ to RT, the current standard of care for newly diagnosed GBM patients has been revised to 6 weeks of RT delivered in 1.8-2.0-Gy daily fractions to a total dose of $60 \mathrm{~Gy}$, followed by adjuvant TMZ CT. ${ }^{6}$ However, the Stupp et al. study excluded patients of age $>70$ years. The alternative treatment for elderly GBM patients primarily includes hypofractionated RT (HRT), in which large fractions of radiation are administered over a short period of time (11). In certain cases, concurrent TMZ combined with HRT has been used despite the lack of established superiority of HRT combined with concurrent TMZ to that of HRT alone. ${ }^{12}$ In our study, the patients were treated with a simultaneous application of $75 \mathrm{mg} / \mathrm{m}^{2} \mathrm{TMZ}$ and 60-Gy RT.

The median OS for patients with GBM is approximately $12-15$ months. ${ }^{6,13,14}$ In our study, the median survival time of all patients was found to be 9.8 months, which is in accordance with the literature. In addition, when the patients were divided into age groups, their median OS was 28 months in the fifth decade, with a statistically significant difference in comparison to patients in their sixth, seventh, and eight decades of life.
Age is considered to be the most important prognostic factor in patients with GBM. Elderly patients have particularly poor prognosis and their median OS is also extremely low. ${ }^{15}$ The median OS for elderly patients with GBM has been reported to be approximately $4-8$ months. ${ }^{2,8-10,16,17}$ No differences in the OS time, progression-free survival time, and quality of life have been noted among patients receiving different RT regimens. ${ }^{18,19}$ In our study, the median survival time of elderly patients was 4 months, which agrees with the reports of some previous studies. However, a statistically significant difference was noted in patients in their eight decade of life as compared to that in younger patients.

Various studies in the literature have revealed that age is the most common and important prognostic variable for GBM. ${ }^{20,21}$ Notably, according to our results, age alone is an important factor in the decision-making for treatment selection. Nevertheless, the most suitable treatment option should not be selected on the basis of the age factor alone, it should, in fact, consider the patient's overall health status, desires, and expectations.

Our study has some limitations. First, it was a retrospective study conducted at a single center, thereby requiring caution while interpreting the results. Second, this retrospective report includes patients treated in 16-year period. During this period, the imaging modalities and RT techniques improved, which may have resulted in a selection bias. Lastly, while we only investigated the chronological age, comorbidities and smoking habits may also be important parameters for patient selection. Moreover, we did not analyze the quality of life. Moreover, neither the methylguanine DNA methyltransferase methylation status nor the IDH1/2 mutation status testing was existing during the study period. Both these markers have been now shown to have significant prognostic and predictive importance in GBM patients. ${ }^{22,23}$ Nevertheless, the findings of the present study are relevant and of significance in analyzing homogenous groups of GBM patients according to age groups.

\section{Conclusion}

GBM remains a poor prognosis and fatal brain tumor despite the availability of multimodal treatment options. Age can be considered as the most 
important prognostic factor in patients with GBM as elderly patients have an extremely poor prognosis. In addition, the median survival rate was found to be good in patients of age $<50$ years, although it decreased for patients of age $>70$ years. Further research is thus warranted for the selection of treatment options that can improve the OS as well as ensure quality of life in the adult patients.

\section{REFERENCES}

1. Rosell R, de Las Peñas R, Balaña C, et al. Translational research in glioblastoma multiforme: molecular criteria for patient selection. Future Oncol 4: 219-228, 2008.

2. Jordan JT, Gerstner ER, Batchelor TT, et al. Glioblastoma care in the elderly. Cancer 122: 189-197, 2016.

3. Dolecek TA, Propp JM, Stroup NE, et al. CBTRUS statistical report: Primary brain and central nervous system tumors diagnosed in the United States in 2005-2009. Neuro Oncol 14: v1-v49, 2012.

4. Rigau V, Zouaoui S, Mathieu-Daudé H, et al. French Brain Tumor DataBase: 5-Year histological results on 25756 cases. Brain Pathol 21: 633-644, 2011.

5. Kandaz M, Guler OC, Yazar U, et al. Impact of peritumoral edema on overall survival in glioblastoma multiforme. Turk $\mathrm{J}$ Oncol 31: 83-88, 2016.

6. Stupp R, Mason WP, van den Bent MJ, et al. Radiotherapy plus concomitant and adjuvant temozolomide for glioblastoma. N Engl J Med 352: 987-996, 2005.

7. Stupp R, Hegi ME, Mason WP, et al. Effects of radiotherapy with concomitant and adjuvant temozolomide versus radiotherapy alone on survival in glioblastoma in a randomised phase III study: 5-year analysis of the EORTC-NCIC trial. Lancet Oncol 10: 459-466, 2009.

8. Vuorinen V, Hinkka S, Farkkila M, et al. Debulking or biopsy of malignant glioma in elderly people- a randomised study. Acta Neurochir (Wien) 145: 5-10, 2003.

9. Paszat L, Laperriere N, Groome P, et al. A population-based study of glioblastoma multiforme. Int J Radiat Oncol Biol Phys 51: 100-107, 2001.

10. Iwamoto FM, Reiner AS, Panageas KS, et al. Patterns of care in elderly glioblastoma patients. Ann Neurol 64: 628-634, 2008.

11. Minniti $G$ and Enrici RM. Radiation therapy for older adults with glioblastoma: Radical treatment, palliative treatment, or no treatment at all? J Neurooncol 120: 225-233, 2014.

12. Cao JQ, Fisher BJ, Bauman GS, et al. Hypofractionated radiotherapy with or without concurrent temozolomide in elderly patients with glioblastoma multiforme: A review of ten-year single institutional experience. J Neurooncol 107: 395-405, 2012.
13. Nieder C, Adam M, Grosu AL. Combined modality treatment of glioblastoma multiforme: The role of temozolomide. Rev Recent Clin Trials 1: 43-51, 2006.

14. Athanassiou H, Synodinou M, Maragoudakis E, et al. Randomized phase II study of temozolomide and radiotherapy compared with radiotherapy alone in newly diagnosed glioblastoma multiforme. J Clin Oncol 23: 2372-2377, 2005.

15. Curran WJ Jr, Scott CB, Horton J, et al. Recursive partitioning analysis of prognostic factors in three radiation therapy oncology group malignant glioma trials. J Natl Cancer Inst 85: 704-710, 1993.

16. Zouaoui S, Darlix A, Fabbro-Peray P, et al. Oncological patterns of care and outcomes for 265 elderly patients with newly diagnosed glioblastoma in France. Neurosurg Rev 37: 415-424, 2014.

17. Keime-Guibert F, Chinot $O$, Taillandier L, et al. Radiotherapy for glioblastoma in the elderly. N Engl J Med 356: 1527-1535, 2007.

18. Guedes de Castro D, Matiello J, Roa W, et al. International Atomic Energy Agency randomized phase III study of radiation therapy in elderly and/or frail patients with newly diagnosed glioblastoma multiforme. Int J Radiat Oncol Biol Phys 98: 931-938, 2017.

19. Konski A, Bracy $P$, Weiss $S$, et al. Cost-utility analysis of a malignant glioma protocol. Int J Radiat Oncol Biol Phys 39: 575-578, 1997.

20. Li J, Wang M, Won M, et al. Validation and simplification of the Radiation Therapy Oncology Group recursive partitioning analysis classification for glioblastoma. Int J Radiat Oncol Biol Phys 81: 623-630, 2011.

21. Burton E, Ugiliweneza B, Woo S, et al. A Surveillance, Epidemiology and end results-medicare data analysis of elderly patients with glioblastoma multiforme: Treatment patterns, outcomes and cost. Mol Clin Oncol 3: 971-978, 2015.

22. Hegi ME, Diserens AC, Gorlia T, et al. MGMT gene silencing and benefit from temozolomide in glioblastoma. N Engl $\mathrm{J}$ Med 352: 997-1003, 2005

23. Yan $\mathrm{H}$, Parsons DW, Jin G, et al. IDH1 and IDH2 mutations in gliomas. N Engl J Med 360: 765-773, 2009.

\section{Correspondence:}

Dr. Mustafa KANDAZ

Karadeniz Teknik Üniversitesi, Tıp Fakültesi

Radyasyon Onkolojisi Anabilim Dalı

61080 TRABZON / TURKEY

Tel: (+90-462) 3775595

e-mail: mkandaz61@gmail.com 